\title{
THE ANALYSIS OF INTEGRATION AND THE IMPACT OF MACROECONOMICS TOWARDS SECTOR STOCK INDEXES IN INDONESIA'S STOCK EXCHANGE: A CASE STUDY IN THE PERIOD OF 2009-2016
}

\author{
Shafadina Ridia*, Hartoyo Sri, Sasongko Hendro \\ School of Business, Bogor Agricultural University, Indonesia \\ *E-mail: ridiashafadina@yahoo.com
}

\begin{abstract}
This study will measure the level of integration that occurs between the Sectoral Index in Indonesia Stock Exchange. This research will also analyze the effect of macroeconomy effect covering exchange rate, inflation, world oil price, and interest rate on Sectorial Index in Indonesia Stock Exchange. The analysis method used is VAR and VECM. The data analysis uses VAR/VECM includes three major analysis tools namely Johannsen cointegration test, Impulse Response Function (IRF), and Forecast Error Variance Decomposition (FEVD). The research results show that there is integration between sectoral shares in Indonesia Stock Exchange. The nine sectors responded negatively to the inflationary shock and $\mathrm{BI}$ rate. Meanwhile, they responded positively on the world oil price shock. Exchange rate shock was responded positively by the basic and chemical industry sectors, consumer goods industry sector, property and real estate sectors, miscellaneous industry sector, consumer goods industry sector, property and real estate sectors, transportation and infrastructure sectors, financial and trade, services, and investments sectors. While the agricultural sector, mining sector, and various sectors of the industry responded negatively against the exchange rate shock.
\end{abstract}

\section{KEY WORDS}

Sectoral stock index, integration, macroeconomics, VAR/VECM.

Capital market is one of public investment means which directly plays a role in the process of changing economic condition of a country continuously. The development of the capital market industry increases the interest of investors to invest their assets in the stock industry. Investing in shares allows investors and business actors to earn huge profit. However, it can also cause big loss in a short period of time. Thus, the investor needs information to read the movement of stock prices.

The development of stock industry in Indonesia can be seen through Indonesia Composite Index or known as IHSG or ICl. The Indonesia Composite Index reflects the stock price condition of all companies listed on the IDX. Companies within BEI are divided into sectors namely agriculture, mining, basic and chemical industries, various industries, consumer goods, property and real estate, transportation and infrastructure, finance, trade, services and investment, and manufacturing. The stock price movement of each sector is illustrated in the Sectoral Stock Price Index (IHSS).

The phenomenon of capital market integration has created a domino effect or Contagion Effect. Sectoral integration can be defined as the movement of several stock sectors to one long-term equilibrium with the same or similar pattern caused by the similarity of factors affecting the sector or the dependence of one sector to another. Hence, when there is turmoil in one sector caused by global factors it will be responded by other sectors quickly.

The contagion effect can be caused by the interdependence of economic relations such as macroeconomic equality. Macroeconomic factors that affect the stock indexes include changes in central bank interest rate, global economic condition, world energy price, political stability of a country, etc. (Blanchard 2006).

This study will measure the level of integration that occurs between Sectoral Index in Indonesia Stock Exchange such as agriculture, mining, basic and chemical industries, 
various industries, consumer goods, property and real estate, transportation and infrastructure, finance, trade and services and investment. Integration will definitely cause contagion effect. Thus, it is interesting to study about which dominant sector in Indonesia stock market. This research also analyzes the influence of macroeconomic factors including exchange rate, inflation, world oil price and interest rate on Sector Index in Indonesian Stock Exchange. Hence, if macroeconomic shock which affect one sector, investors can anticipate the impact that will occur in other sectors.

\section{METHODS OF RESEARCH}

The analytical methods used are VAR and VECM. Data analysis using VAR / VECM includes three main analysis tools namely Johannsen cointegration test, the method used to determine whether the variables are not cointegrated stationary or not, Impulse Response Function (IRF), the method used to determine the response of an endogenous variable to a certain shocks and Forecast Error Variance Decomposition (FEVD), a method that can be done to see how changes in a variable indicated by variance error changes are influenced by other variables.

VECM is often referred to as the VAR design for non-stationary series that has a cointegration relationship. Thus, in VECM there is a speed of adjustment from short to long term (Paradise 2011). The specifications of the VAR model are in the form of a matrix as follows:

$$
\left[\begin{array}{c}
J K A G R I_{t} \\
J K M I N G_{t} \\
J K B I N D_{t} \\
J K M I S C_{t} \\
J K C O N S_{t} \\
J K P R O P_{t} \\
J K I N F A_{t} \\
J F I N A_{t} \\
J K T R A D E_{t} \\
I F_{t} \\
B R_{t} \\
H M_{t} \\
K R_{t}
\end{array}\right]=\left[\begin{array}{c}
a_{0} \\
b_{0} \\
c_{0} \\
d_{0} \\
e_{0} \\
f_{0} \\
g_{0} \\
h_{0} \\
i_{0} \\
j_{0} \\
k_{0} \\
l_{0} \\
m_{0}
\end{array}\right]+\left[\begin{array}{ccc}
a_{11} & \cdots & a_{113} \\
\vdots & \ddots & \vdots \\
a_{131} & \cdots & a_{1313}
\end{array}\right]\left[\begin{array}{c}
J K A G R I_{t-i} \\
J K M I N G_{t-i} \\
J K B I N D_{t-i} \\
J K M I S C_{t-i} \\
J K C O N S_{t-i} \\
J K P R O P_{t-i} \\
J K I N F A_{t-i} \\
J F I N A_{t-i} \\
J K T R A D E_{t-i} \\
I F_{t-i} \\
B R_{t-i} \\
H M_{t-i} \\
K R_{t-i}
\end{array}\right]+\left[\begin{array}{c}
\varepsilon_{1 t} \\
\varepsilon_{2 t} \\
\varepsilon_{3 t} \\
\varepsilon_{4 t} \\
\varepsilon_{5 t} \\
\varepsilon_{6 t} \\
\varepsilon_{7 t} \\
\varepsilon_{8 t} \\
\varepsilon_{9 t} \\
\varepsilon_{10 t} \\
\varepsilon_{11 t} \\
\varepsilon_{12 t} \\
\varepsilon_{13 t}
\end{array}\right]
$$

Where:

JKAGRI = price of the agricultural sector index;

JKMING = price of the mining sector index;

$\mathrm{JKBIND}=$ price index of basic industry \& chemical sector;

JKMISC $=$ price of various industry sector indices;

JKCONS = price index of the consumer goods sector;

JKPROP = price index of property \& real estate sector;

JKINFA = price index of the transportation \& infrastructure sector;

JKFINA = price of the financial sector index;

JKTRADE = price index of trade services sector and investment;

IF = inflation;

$\mathrm{BR}=\mathrm{BI}$ Rate

$\mathrm{HM}=$ World Oil Prices;

$\mathrm{KR}=$ Exchange rate;

$\mathrm{A} 0=$ vector intercept;

$A 1=$ matrix coefficient or parameter size (n.n) for every $i=1,2, \ldots, p$;

$\varepsilon t=$ error-sized vector . 


\section{RESULTS AND DISCUSSION}

Macroeconomic Condition. The ability of investors to understand and forecast future macroeconomic condition will be very useful in making profitable investment decisions. To that end, an investor should pay attention to some macroeconomic indicators that can help them in understanding and predicting macroeconomic conditions. Observing changes in some variables or economic indicators can help investors in predicting what will happen to change in the capital market.

Inflation is a state where the decline in the value of a country's currency resulting in a systematic increase in the price of goods. Figure 1 describes the macroeconomic conditions during 2009-2016. The fluctuation in inflation can be seen in the picture. Inflation can occur due to two things namely the rising demand, production cost, and it can also be caused by the amount of money supply in the community. Unstable food prices in Indonesia are suspected to be one of the causes of inflation fluctuation.

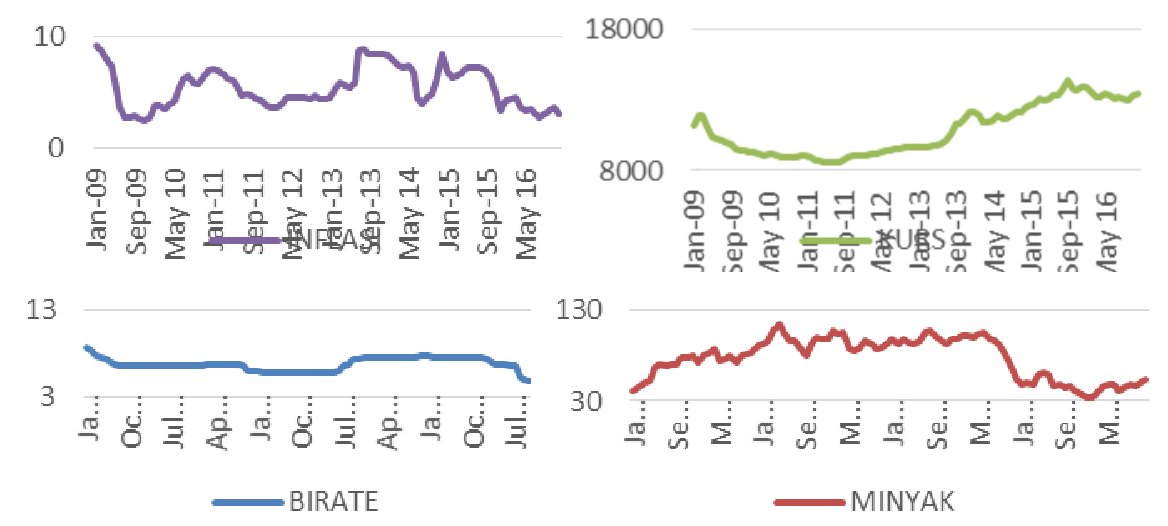

Figure 1 - Macroeconomic chart, 2009-2016

Currency exchange rate or exchange rate had decreased in 2009 to 2011. However, rupiah continues to weaken since 2011 . BI rate is a policy rate that reflects the stance of monetary policy stipulated by Bank of Indonesia and it is announced to the public. It can be seen in the picture that the $\mathrm{BI}$ rate has decreased in 2016. World oil prices had decreased drastically in 2015. The reason is that OPEC decided the policy that not restricting the production in order to maintain market share. Hence, resulting in the abundant supply of world oil.

Pre-Estimation Test. In using VAR/VECM, the data used must be previously tested. Testing data is done to determine the model used, then it can be determined whether VAR or VECM. The tests carried out include stationary test, cointegration test, causality test, VAR/VECM test, IRF test, and variance decomposition.

The results of the data stationarity test on the first difference shows that all variables used in the study have been stationary at first difference level. This is because the probability value is less than 0.05 .

In determining the optimal lag using the information criteria, the criterion is chosen which has the smallest value indicated by asterisk $\left(^{*}\right)$ in the optimal lag result. The table shows that the optimal lag length is one (1) seen from the value of FPE, AIC, SC, and HQ.

A VAR system is said to be stable if all roots or its roots have a modulus smaller than one. In the test results it can be concluded that the estimation of the stability of VAR to be used for IRF and FEVD analysis has been stable because of the modulus range $<1$. Hence, it can be used for further analysis.

Integration between Sectoral Shares Index. In looking at stock exchange integration, there are five usable analyzes such as correlation analysis, causality, cointegration, variance decomposition, and asset pricing model (Tony et al 2004). In this study, only three analyzes 
are used in the VAR/VECM method namely causality, cointegration, and variance decomposition analysis.

Cointegration testing is carried out to obtain long-term relationship between variables that have met the requirements during the integration process where all variables have stationer at the same degree which is the degree one I (1). The VECM estimation is performed when cointegration is found. On the contrary, if there is no cointegration, then the VAR in difference estimation will be performed.

The cointegration test used in this research is the Johansen cointegration test by comparing the trace statistic value and the Max-Eigen statistic value with the critical value of 0.05 . If the trace statistic value and Max-Eigen statistic value are greater than the critical value of 0.05 , then the data is cointegrated and vice versa. If the trace statistic value and the Max-Eigen statistic value are less than the critical value of 0.05 then the data is not cointegrated.

Integration between sectoral stock price index. The result of cointegration test from trace test statistic shows that there are 8 cointegrated equations and significant at $\alpha=5 \%$. Furthermore, the maximum eigenvalue test statistic shows that there are 2 cointegrated equations and significant at $\alpha=5 \%$. It can be seen from the value of Prob. $<0.05$ which means there is a cointegration between sectoral stock index variables in Indonesia Stock Exchange and macroeconomic variables. VECM mode is used because the existence of integration.

Long-Term and Short-Term Relationships between Variables. The result of VECM estimation will obtain short and long-term relationship between each variable. Estimation of VECM is carried out when the existence of cointegration between variables is found in cointegration test. Cointegration between variables is found in the cointegration test. Hence, VECM estimation is carried out.

The estimation results show that the agricultural sector has a positive influence on basic and chemical industry sector equal to $0.122 \%$. This means that an increase in the agricultural sector will cause the increase in basic industrial and chemical sector by $0.122 \%$. In addition to the agriculture sector property and real estate, and the $\mathrm{BI}$ rate has a positive influence on basic and chemical industry sectors. Meanwhile the mining sector has no influence on the basic and chemical industry sectors.

The agricultural sector has a negative effect on the consumer goods sector by $0.095 \%$. This means that an increase in the agricultural sector will cause the decline in the consumer goods sector of $-0 / 095 \%$. In addition to agricultural sector, another variable that has a negative effect on the consumer goods sector is the $\mathrm{BI}$ rate of $-82.57 \%$. While the exchange rate, inflation, and property and real estate sector have no effect on the consumer goods sector.

In addition to long-term, VECM estimation also analyses the short-term effects. The results of VECM estimation which have short term effect are presented in the table 9.

Table 2 - Short-term VECM estimation

\begin{tabular}{cccc}
\hline Dependent Variable & Independent Variable & Coefficient & t statistics \\
\hline JKBIND & D(BIRATE(-1)) & 39.69413 & {$[2.61658]$} \\
JKAGRI & D(INFLASI(-1)) & -9.89116 & {$[-2.80459]$} \\
JKFINA & D(JKMISC(-1)) & -2.47479 & {$[-2.53448]$} \\
JK INFA & D(INFLASI(-1)) & -13.4055 & {$[-2.71014]$} \\
& D(INFLASI(-1)) & -14.733 & {$[-2.49841]$} \\
& D(JKBIND(-1)) & -2.73892 & {$[-1.97612]$} \\
JKMISC & D(JKCONS(-1)) & -1.61145 & {$[-2.28632]$} \\
& D(JKFINA(-1)) & -7.08564 & {$[-2.31249]$} \\
& D(JKINFA(-1)) & -2.48084 & {$[-2.30561]$} \\
& D(JKMING(-1)) & -0.66884 & {$[-2.10811]$} \\
\hline
\end{tabular}

Table 2 shows that $\mathrm{BI}$ rate affects basic and chemical industry sectors positively while and inflation affects basic and chemical industry sectors negatively. The various industry 
sectors affect the agriculture sector negatively by $-2.274 \%$. This means that an increase in the miscellaneous industry sector will cause a decrease in the agribusiness sector by $2.474 \%$.

Inflation affects the transportation and infrastructure sectors as well as financial sector negatively. The miscellaneous industry sector is mostly affected by other sectors as many as 7 sectors. The sectors affecting various industry sectors include basic and chemical industry sectors, consumer goods sector, financial sector, transportation and infrastructure sectors, mining sector, miscellaneous industry sector, and trade, services and investment sectors. All sectors negatively affect miscellaneous industry sector. It states that the miscellaneous industry sector declines when there is an increase in other sectors.

Macroeconomic Relationship with Sectoral Stock Index. The Granger causality test is performed to see if two variables have a reciprocal relationship or not. In other words, one variable has a causal relationship with other variables significantly, since each variable in the study has an opportunity to be an endogenous or exogenous variable. The bivariate causality test uses the VAR Pairwise Granger Causality Test and using a real five percent rate. The table results of Bivariate Granger Causality test analysis can be seen in the appendix, while the results of causality test can be seen in the following table.

Table 3 - Causality test results

\begin{tabular}{|c|c|c|c|c|c|c|c|c|c|}
\hline \multirow{2}{*}{ Independent variable } & \multicolumn{9}{|c|}{ Dependent variable } \\
\hline & JKagri & JKbind & JKming & Jkmisc & Jkinfa & Jkprop & Jktrade & Jkfina & Jkcons \\
\hline Kurs & $\checkmark$ & $\checkmark$ & $\checkmark$ & $\checkmark$ & $\sqrt{ }$ & $\checkmark$ & $\checkmark$ & $\checkmark$ & $\checkmark$ \\
\hline BI Rate & $\checkmark$ & $\checkmark$ & $\checkmark$ & $\checkmark$ & $\checkmark$ & $\checkmark$ & $\checkmark$ & $\checkmark$ & $\checkmark$ \\
\hline Inflasi & $\checkmark$ & $\checkmark$ & $\checkmark$ & $\checkmark$ & $\checkmark$ & $\checkmark$ & $\checkmark$ & $\checkmark$ & $\checkmark$ \\
\hline Minyak & $x$ & $\checkmark$ & $\checkmark$ & $\checkmark$ & $\checkmark$ & $\checkmark$ & $\checkmark$ & $\checkmark$ & $\checkmark$ \\
\hline JKagri & & $\checkmark$ & $x$ & $\checkmark$ & $\checkmark$ & $\checkmark$ & $\checkmark$ & $\checkmark$ & $\checkmark$ \\
\hline JKbind & $\checkmark$ & & $x$ & $\checkmark$ & $\checkmark$ & $\checkmark$ & $x$ & $\checkmark$ & $\checkmark$ \\
\hline JKming & $\checkmark$ & $\checkmark$ & & $\checkmark$ & $x$ & $\checkmark$ & $\checkmark$ & $\checkmark$ & $\checkmark$ \\
\hline Jkmisc & $\checkmark$ & $\checkmark$ & $x$ & & $\checkmark$ & $\checkmark$ & $x$ & $\checkmark$ & $\checkmark$ \\
\hline Jkinfa & $\checkmark$ & $\checkmark$ & $x$ & $\checkmark$ & & $\checkmark$ & $\checkmark$ & $\checkmark$ & $\checkmark$ \\
\hline Jkprop & $\checkmark$ & $\checkmark$ & $\checkmark$ & $\checkmark$ & $\checkmark$ & & $\checkmark$ & $\checkmark$ & $\checkmark$ \\
\hline Jktrade & $\checkmark$ & $\checkmark$ & $\checkmark$ & $\checkmark$ & $\checkmark$ & $\checkmark$ & & $\checkmark$ & $\checkmark$ \\
\hline Jkfina & $\checkmark$ & $\checkmark$ & $x$ & $\checkmark$ & $\checkmark$ & $\checkmark$ & $\checkmark$ & & $\checkmark$ \\
\hline Jkcons & $\checkmark$ & $\checkmark$ & $x$ & $\checkmark$ & $\checkmark$ & $\checkmark$ & $\checkmark$ & $\checkmark$ & \\
\hline
\end{tabular}

Note: $\checkmark$ has effect; $x$ has no effect.

The results of causality test show that macroeconomic variables include exchange rate, $\mathrm{BI}$ rate, and inflation have reciprocal relation to nine existing sectors namely agriculture sector, mining sector, basic and chemical industry sectoral, miscellaneous industry sector, consumer goods industry sector, property and real estate sectors, miscellaneous industry sectors, consumer goods industry sector, property and real estate sectors, transportation and infrastructure sector, financial sector, and trade, services and investment sectors. In addition, the world oil price affects the eight other sectors except the agricultural sector. This shows that the correlation of agriculture with world oil price is very low or almost nonexistent.

The agricultural sector affects almost all other sectors except the Mining Sector. This shows that the correlation between the agricultural sector and the mining sector is very small or absent. The statement is supported by the results of world oil price causality test which has no effect on Agricultural Sector. Table 3 shows that the mining sector is only affected by the property sector and real estate and trade, services and investment sectors. This indicates that the movement of stock price index of mining sector is not correlated with index of share price of agriculture sector, basic industry and chemical schemer, multifarious industry sector, consumer goods industry sector, transportation and infrastructure sector, and financial sector.

The property and real estate sectors as well as trade, services and investment sectors affect the other eight sectors. It shows that stock index movement of property and real estate, trade, service and investment sectors have reciprocal relation of index of stock price of other sectors. 
The Effects of Macroeconomic Shock on IHSS. The dynamic behavior of the VECM model can be seen through the response of each variable to the shock of the other variables. Impulse Response Function (IRF) provides an overview of how the response of a variable in the future if there is an interference with one of the variables. Thus, it can be seen the duration of the influence of the shock of a variable against another variable until the influence is lost or returned to the point of balance. In the IRF graph, the horizontal axis represents the time period ahead after the shock, while the vertical source is the response value. Fundamentally, through this analysis it will be known the positive or negative response of a variable to the other variables that can be observed from the graph in the first and third quadrant only because the second and fourth quadrant shows the response of each variable itself.

The IRF analysis will explain the impact of shock on one variable to the other variables where this analysis will not only analyze in short time but also analyze for some future horizons as long-term information. In this analysis, there is a long-term dynamic response to each variable when there is a certain shock of one standard error in each equation.

In IRF, it is known that the period of time required until a sector reaches a stable point to the macroeconomic shocks illustrated in Figure 3

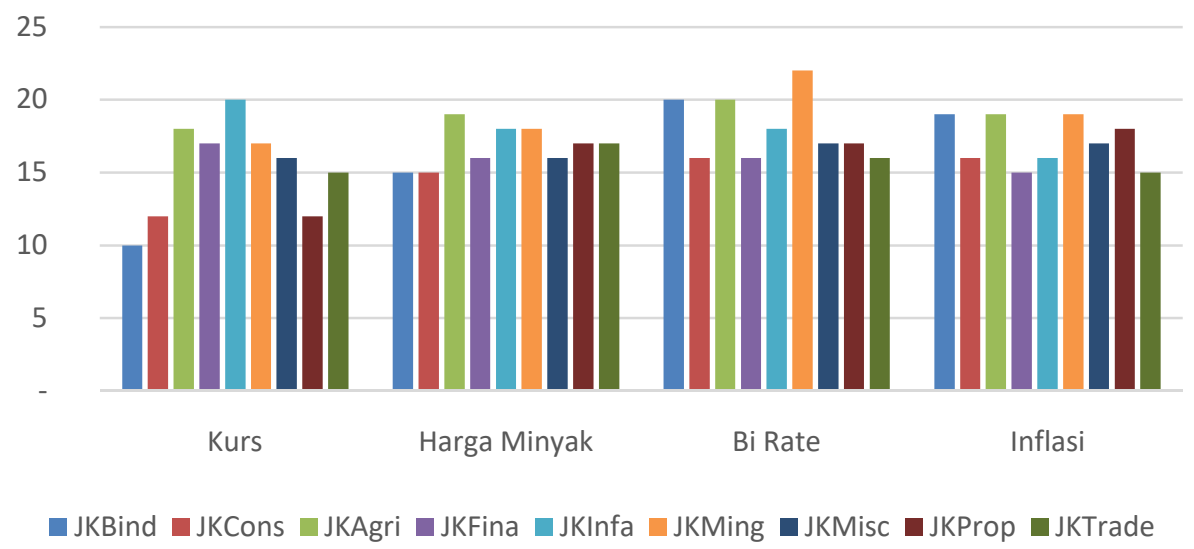

Figure 2 - IRF Stable Period

Figure 2 outlines the time required for a sectoral stock price index to be stable against macroeconomic shocks. In Figure 3 it can be seen that the multifarious industry sector has the shortest period in reaching a stable point against shocks at the exchange rate. While the financial and investment sectors have the longest period in reaching a stable point against exchange rate shocks.

The nine sectors are agriculture, mining, basic and chemical industry, miscellaneous industry sectors, consumer goods industry sector, property and real estate sector, miscellaneous industry sectors, consumer goods industry sector, property and real estate sectors, transportation and infrastructure sectors, the financial sector, and the trade, services and investment sectors respond negatively to inflation shock. Samsul (2008) states that high inflation will bring down stock prices in the market, while very low inflation will result in very slow economic growth, and ultimately stock prices will also move slowly.

The shock to world oil price were positively responded by the nine factors, namely agriculture, mining, basic and chemical industry, miscellaneous industry, consumer goods sectors, property and real estate, miscellaneous industry, consumer goods industry, property and real estate sectors, transport and infrastructure sectors, financial sector, and trade, services and investment sectors. The agriculture and miscellaneous industry sectors responded negatively at the beginning of the period but as the period progressed the response increased to a positive response. 
The role of fluctuations in the price of oil on capital markets will depress the prospect of shares with certain characteristics, the first stocks of companies whose raw materials are mostly import-based, such as stocks of infrastructure and consumer goods sector will fall, then stock issuers who have lots of US dollar debt and risk bear foreign exchange losses, and the last is the stock of banks and property. Because with rising oil prices can cause trade balance deficits, then can raise the rate $\mathrm{BI}$ rate.

Agricultural sector, mining sector, basic and chemical industry, miscellaneous industry sector, consumer goods industry sector, property and real estate sector, miscellaneous industry sector, consumer goods industry sector, property and real estate sector, transportation and infrastructure sector, financial sector, and the overall trade, services and investment sectors responded negatively to $\mathrm{Bl}$ rate shocks. Basic and chemical industrial sector, consumer goods sector, and transportation sector infrastructure respond positively to $\mathrm{BI}$ rate shock at the beginning of the period but respond negatively in the next period. Satya (2015) states that high interest rates are a negative signal for stock prices. This is because the increase in interest rates will increase the burden of credit interest and lower net income. A decrease in net profit will result in lower earnings per share and will eventually result in lower stock prices in the market. On the other hand, rising interest rates on deposits will encourage investors to sell stocks and then save the proceeds in deposit.

The shocks to the exchange rate are positively responded by basic and chemical industry sectors, consumer goods industry sector, property and real estate sector, miscellaneous industry sector, consumer goods industry sector, property and real estate sector, transportation and infrastructure sector, financial sector and trade sector, services, and investments. While the agricultural sector, mining sector, and various sectors of the industry negatively respond against exchange rate shocks. Samsul (2008) states that a sharp increase of US dollar exchange rate against the rupiah will negatively impact the issuer with dollar debt while the issuer's products are sold locally. Meanwhile, export-oriented issuers will receive a positive impact from the rise in the exchange rate. This means that the negatively affected stock price of the issuer will decline in the Stock Exchange, while the positively affected issuer will increase its stock price.

Relationship of IHSG and IHSS. The stock market has become more integrated due to the increasing importance of free capital mobility arising from various economic integration mechanisms (Narayan 2004). Fauzi (2009) states that the integration process can occur due to several things, including policies between countries, investor characteristics, and stock market characteristics in the country. The relationship between IHSG and IHSS is outlined in the following variance decomposition results. In the cointegration test result there is integration on sectoral stock price index in BEI 2009-2016 period.

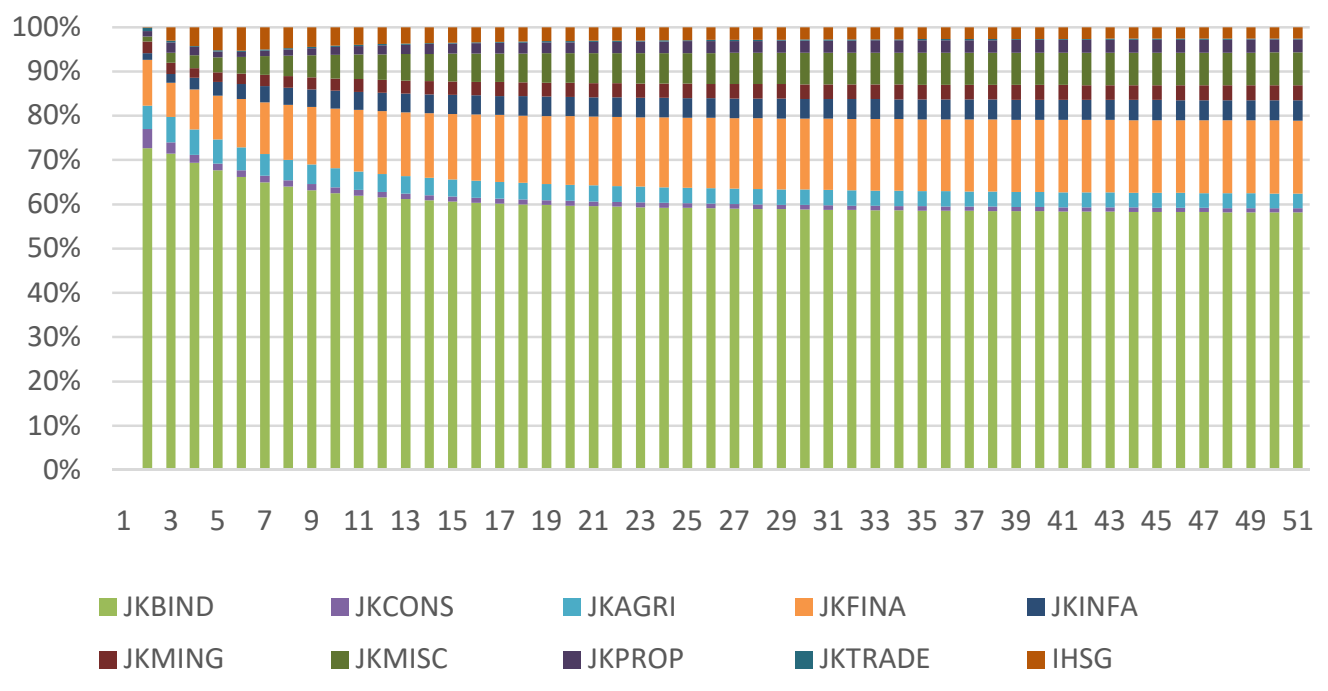

Figure 3 - Variance decomposition of IHSG 
Based on Figure 4, the $\mathrm{JCl}$ fluctuation is largely influenced by the contribution of basic and chemical industry sectors (BIND), basic and chemical industries have contributed more than $70 \%$ and followed by the financial sector. While the lowest contribution in $\mathrm{JCl}$ fluctuations is the trade, services and investment (JKTRADE) sector, which is less than $1 \%$. The high contribution of basic and chemical industries is influenced by various sub-sectors such as cement, chemical, metal, ceramic, feed and wood.

Manu (2016) states that there is a contagion effect between sector index in Indonesia Stock Exchange where Financial sector index is the leader of other sector index in Indonesia Stock Exchange. The statement of sectoral sector leaders differs from this study which states that the index of basic and chemicals industry sectors has the largest contribution in the composite stock price index. This is due to the difference in the period measured in January 2007 - December 2015.

\section{MANAGERIAL IMPLICATIONS}

For investors, this research is expected to be a consideration for investing in Indonesia stock exchange. Given the results of this study, investors can see which sectors are strongly related to other sectors. Investors can also see the response given by each sector if there is positive or negative shock to macroeconomics. Losses on stock investments can also be avoided or reduced by looking at relationships between sectors and with macroeconomic factors.

For issuers with integrity among sectoral shares, companies can cooperate in advancing the company's performance. Given the integration between sectoral stocks, it is hoped that there will be a mutually beneficial policy for all sectors in the future. Issuers can also anticipate the macroeconomic shocks that occur.

\section{CONCLUSION AND RECOMENDATIONS}

There is integration between sectoral stocks in Indonesia Stock Exchange. This means that there is a relationship between sectors. Exchange rate, $\mathrm{BI}$ rate and inflation have causality relation with nine sectors, namely agriculture sector, mining sector, basic and chemical industry sectors, miscellaneous industry sector, consumer goods industry sector, property and real estate sectors, miscellaneous industry sector, consumer goods industry sector, property and real estate sectors, transport and infrastructure sectors, financial sector, and trade, services and investment sectors. While world oil prices affect the other eight sectors except the agricultural sector.

The nine sectors respond negatively to inflation and $\mathrm{BI}$ rate inflationary shocks, while respond positively to the world oil price shock. The shock to the exchange rate is positively responded by basic and chemical industry sectors, consumer goods industry sector, property and real estate sectors, miscellaneous industry sectors, consumer goods industry sector, property and real estate sectors, transportation and infrastructure sectors, financial and trade sectors, services, and investments. While the agricultural sector, mining sector, and various sectors of the industry respond negatively against the exchange rate shock.

Various industry sectors have the largest contribution among other sectors in price fluctuations experienced by $\mathrm{JCl}$. While sectors per trade, service, and investment have the lowest contribution in influencing $\mathrm{JCl}$ fluctuation

The suggestion in this research refers from various shortcomings found in the study. One of the shortcomings is not using return as the variable. The future research can use return variable of stock price index. In addition, macroeconomy variable can be added such as GDP and the money supply. Further research can also examine the integration and influence of macroeconomic factors on stock returns. 


\section{REFFERENCES}

1. Blanchard O. 2006. European unemployement: the evolution of facts and ideas. Working Paper. 21.

2. Fauzi AJFA. 2009. Transmisi harga dan volatilitas saham saham dunia: kajian empiris sebelum dan setelah krisis subprime mortgage [tesis]. Bogor (ID): Institut Pertanian Bogor.

3. Manu PMB. 2016. Integrasi sektoral pasar modal (studi kasusa pada indeks saham asing dan indeks sektoral di Bursa Efek Indonesia periode Januari 2007 - Desember 2015). Jurnal IImiah Mahasiswa FEB Universitas Brawijaya 4(2).

4. Narayan P. 2004. Interdependence and dynamic linkages between the emerging stock markets of South Asia. Accounting and Finance. 44:419-439.

5. Samsul M. 2008. Pasar Modal dan Manajemen Portofolio. Jakarta (ID):Erlangga.

6. Satya 2015. Dampak penuruna BI rate terhadap perekonomian nasional. Info Singkat, Ekonomi dan Kebijakan Publ ik. 2(4):13-16. 